\title{
THE IMPACT OF MICRO ECONOMICS FACTORS ON FINANCIAL PERFORMANCE OF ISLAMIC BANKS IN INDONESIA
}

\author{
Agus Ahmad Nasrulloh \\ Program Studi Ekonomi Syariah, Fakultas Agama Islam, Universitas Siliwangi \\ Jl. Siliwangi No. 24 Kota Tasikmalaya 46115 \\ agusahmad@unsil.ac.id
}

\begin{abstract}
Abstrak
Profitabilitas (ROA) pada perbankan syariah merupakan salah satu hal terpenting yang harus diperhatikan oleh pihak manajemen keuangan. Penulis tertarik untuk menganalisis faktorfaktor yang mempengaruhi terhadap profitabilitas (ROA) yaitu FDR, DPK, NPF dan Pembiayaan. Penelitian ini adalah penelitian empiris pada 9 perbankan syariah di Indonesia dengan 6 tahun periode pengamatan yaitu 2010-2015. Metode yang digunakan dalam penelitian ini adalah analisis kuantitatif analitis dengan pendekatan studi empiris. Teknik pengumpulan data melalui data sekunder yaitu data yang diperoleh dari situs web, literature. Alat analisis yang digunakan adalah Ordinary Lease Square (OLS). Selama periode pengamatan menunjukkan bahwa data penelitian berdistribusi normal. Hasil penelitian ini menunjukkan bahwa secara parsial variabel Financing To Deposit Ratio (FDR), Dana Pihak Ketiga (DPK) dan Pembiayaan tidak berpengaruh terhadap Profitabilitas (ROA), sedangkan Non Performing Finance (NPF) menunjukkan pengaruh yang negative signifikan terhadap Profitabilitas (ROA).
\end{abstract}

\section{Kata Kunci: ROA, OLS, micro economics}

\begin{abstract}
Profitability (ROA) in sharia banking is one of the most important things that must be considered by the financial management. The author is interested to analyze the factors that affect the profitability (ROA) of FDR, DPK, NPF and Financing. This research is empirical research on 9 syariah banking in Indonesia with 6 year observation period that is 2010-2015. The method used in this research is analytical quantitative analysis with empirical study approach. Technique of collecting data through secondary data that is data obtained from website, literature. The analytical tool used is Ordinary Lease Square (OLS). During the observation period showed that the research data is normally distributed. The results of this study indicate that partially variable Financing To Deposit Ratio (FDR), Third Party Fund (DPK) and Financing has no effect on Profitability (ROA) while Non Performing Finance $(N P F)$ shows significant negative effect on Profitability (ROA).
\end{abstract}

\section{Keyword: ROA, OLS, micro economics}




\section{PENDAHULUAN}

Bank syariah adalah lembaga keuangan yang dalam operasionalnya memiliki dua tujuan, yaitu profit oriented dan fallah oriented. Tidak disalahkan jika salah satu tujuan dari kegiatan operasional bank syariah adalah untuk mencari keuntungan secara materi, karena dari keuntungan itulah bank syariah bisa survive.

Jenis lembaga keuangan yang satu ini lahir di negara Indonesia pada tahun 1991, yang dimulai dengan didirikannya Bank Muamalat Indonesia. Kehadirannya memberikan corak baru bagi dunia bisnis di bidang jasa keuangan (pendanaan dan pembiayaan), karena prinsip yang dipegang oleh bank syariah berbeda dengan lembaga keuangan lain pada umumnya, yaitu menerapkan prinsip profit and losh sharing.

Sebagaimana disampaikan di awal, bank syariah merupakan salah satu bagian dari lembaga atau perusahaan bisnis yang bergerak di bidang jasa keuangan. Bisnis itu sendiri adalah suatu kegiatan yang dilakukan secara terus menerus yang orientasinya adalah untuk memperoleh keuntungan, atau dapat diartikan profit oriented. Tidak dapat dikatakan bisnis jika suatu kegiatan tujuannya adalah bukan untuk memperoleh keuntungan secara materi. Kegiatan bisnis ini dapat dilakukan oleh dua orang atau lebih, baik yang sudah bernaung dalam sebuah perusahaan atau belum.

\begin{tabular}{|c|c|}
\hline & \\
\hline $\begin{array}{r}\text { Menurut } \\
\text { utama }\end{array}$ & $\begin{array}{l}\text { Firmansyah } \\
\text { perusahaan }\end{array}$ \\
\hline
\end{tabular}
memperoleh keuntungan (laba) melalui potensi yang dimilikinya. Semakin besar keuntungan maka semakin baik operasional perusahaan. Sebagai agen yang diamanatkan oleh pemegang saham, manajemen akan berusaha untuk memberikan yang terbaik demi tercapainya tujuan yang telah ditetapkan.

Salah satu ukuran untuk mengetahui pencapaian profitabilitas dalam perbankan adalah dengan melihat perkembangan Return On Asset (ROA), yang memfokuskan pada kemampuan perusahaan untuk memperoleh pendapatan dalam operasi perusahaan. ROA digunakan untuk mengukur profitabilitas bank karena Bank Indonesia sebagai pembina dan pengawas perbankan lebih mengutamakan nilai profitabilitas suatu bank yang diukur dengan aset yang dananya sebagian besar dari dana simpanan masyarakat. Selain itu $R O A$ digunakan untuk mengukur efektivitas perusahaan di dalam menghasilkan keuntungan dengan memanfaatkan aktiva yang dimilikinya. (Rima Yunita, 2014).

Membahas tentang profitabilitas (ROA), berikut di bawah ini adalah 
Agus Ahmad N. : The Impact Of Micro Economics Factors on Financial Performance..

kondisi ROA perbankan syariah di Indonesia pada tahun 2010-2015 :

Tabel 1:ROA Perbankan Syariah di Indonesia

\begin{tabular}{|c|c|}
\hline Tahun & ROA $(\%)$ \\
\hline 2010 & 1.67 \\
\hline 2011 & 1.79 \\
\hline 2012 & 2.14 \\
\hline 2013 & 2.00 \\
\hline 2014 & 0.80 \\
\hline 2015 & 1.81 \\
\hline
\end{tabular}

Berdasarkan data diatas, jika dibuat ke dalam sebuah grafik maka dapat dilihat pada gambar di bawah ini :

Gambar 1.

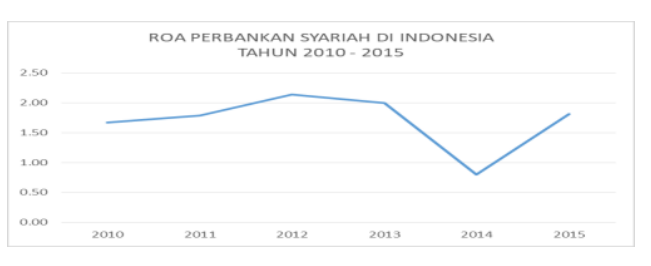

Grafik dan tabel diatas memperlihatkan bahwasanya kondisi profitabilitas/ Return On Asset (ROA) perbankan syariah di Indonesia mengalami kondisi yang fluktuatif. Tahun 2010-2012 trennya mengalami kenaikan, akan tetapi pada tahun 2013 mengalami penurunan yang diikuti oleh penurunan pada tahun 2014 yang sangat signifikan, dan tahun 2015 terjadi peningkatan kembali. Kondisi ini dapat diinterpretasikan bahwa ROA pada lima tahun tersebut tidak stabil, yang tentunya dipengaruhi oleh banyak faktor baik itu faktor mikro maupun makro.
Pencapaian profitabilitas yang tidak stabil diatas, agar tidak terjadi secara terus menerus, maka harus dilakukan analisis mengenai faktor mikro apa saja khususnya, yang mempengaruhi kondisi tersebut dan seberapa besar pengaruhnya.

Rasa khawatir muncul jika tindakan untuk menyelesaikan dan langkah pencegahan lambat atau bahkan tidak dilakukan terhadap kondisi ini yang diakibatkan kurang pekanya terhadap keaadan. Salah satu hal yang akan terjadi jika profitabilitas perbankan syariah tidak stabil adalah hilangnya kepercayaan dari nasabah atau investor, terutama kategori nasabah rasional yang karakteristiknya hanya akan bekerjasama dengan perbankan syariah, apabila perbankan syariah yang secara materi mampu memberikan keuntungan lebih besar dibandingkan lembaga keuangan lain seperti perbankan konvensional, begitupun sebaliknya. Dampak lebih buruk yang akan muncul adalah keberlangsungan operasional perbankan syariah sulit untuk berkembang, sehingga akan menghambat pertumbuhan perekonomian negara. Hal ini diperkuat oleh pernyataan Firmansyah (2015), bahwa perbankan sebagai lembaga intermediasi antara pemilik sumber dana dengan pihak yang memerlukan dana, memegang fungsi strategis dalam memajukan pertumbuhan ekonomi suatu 
negara. Peran strategis inilah yang menyebabkan kesinambungan usaha suatu bank perlu pertahankan.

Terdapat banyak penelitianpenelitian terdahulu yang membahas tentang faktor mikro/ internal apa saja yang mempengaruhi profitabilitas perbankan syariah di Indonesa. Diantara beberapa penelitian tersebut diantaranya adalah Rima Yunita (2014), Suryani (2011), Sri Muliawati dan Moh. Khoirudin (2015), Zulfiah dan Susilo wibowo (2014), Ali et al. (2012), dan masih banyak lagi. Hasil dari beberapa penelitian tersebut memberikan hasil yang berbeda-beda. Faktor internal yang diteliti adalah FDR, DPK, NPF dan Pembiayaan.

Berdasarkan latar belakang dan bukti empiris di atas maka perlu diajukan penelitian lanjutan, yang tujuan dan kegunaanya adalah untuk mengetahui pengaruh faktor mikro (internal) yaitu likuiditas (FDR), DPK, kualitas aktiva (NPF) dan pembiayaan terhadap profitabilitas (ROA) perbankan syariah di Indonesia. Hasil dari penelitian ini diharapakan bisa memberikan solusi atau informasi untuk perbaikan performa perbankan syariah ke arah yang lebih bagus dan mampu menarik minat para investor yang lebih banyak, demi menunjang perkembangan perekenomian negara.
Metode penelitian yang digunakan dalam penelitian ini adalah analisis kuantitatif dengan menggunakan teknik perhitungan statistik. Analisis data yang diperoleh dalam penelitian ini menggunakan program aplikasi SPSS Ver. 16. Metode analisis data yang digunakan adalah metode Ordinary Lease Square (OLS). Data diperoleh dari beberapa perbankan syariah yang diperoleh melalui web site resmi masing-masing bank syariah tersebut.

Populasinya adalah bank umum syariah dan unit usaha syariah yang terdaftar di Bank Indonesia pada tahun 2010-2015. Pemilihan sampelnya dengan menggunakan purposive sampling method sebanyak 9 bank. Berikut adalah namanama bank syariah yang dijadikan sampel dengan periode yang sama yaitu 2010 2015: Bank Muamalat Indonesia, BCA Syariah, BJB Syariah, BNI Syariah, Bukopin Syariah, Maybank Syariah, Panin Syariah, Victoria Syariah, dan BRI Syariah.

Langkah analisis regresi yang dilakukan dalam penelitian ini, menurut Ghazali (2009) agar hasilnya baik maka disyaratkan untuk melakukan uji asumsi klasik. Diantaranya: (1) uji multikoliniearitas; (2) uji autokorelasi; (3) uji heteroskedastisitas; dan (4) uji 
Agus Ahmad N. : The Impact Of Micro Economics Factors on Financial Performance..

normalitas. Adapun persamaa regresi data panel yang digunakan adalah:

$\mathrm{ROA}=\alpha+\beta 1 \mathrm{FDR}+\beta 2 \mathrm{Ln} \_\mathrm{DPK}+\beta 3$

$\mathrm{NPF}+\beta 4$ Ln_Pembiayaan $+\varepsilon 1$

Keterangan:

$\alpha=$ Konstanta

$\beta 1, \beta 4=$ Koefisien Determinasi

ROA = Return On Asset

FDR = Financing to Deposit Ratio

Ln_DPK = Dana Pihak Ketiga

$\mathrm{NPF}=$ Non Performing Finance

$\varepsilon 1=$ Error $($ kesalahan pengganggu)

Setelah dilakukan uji asumsi klasik, maka langkah selanjutnya adalah uji hipotesis. Untuk menguji hipoteis, pengujian dilakukan dengan menggunakan uji koefisien regresi secara parsial (Uji t) dan uji koefisien regresi secara bersamasama (Uji F).

\section{PEMBAHASAN}

\section{A. Tinjauan Pustaka dan Hipotesis}

\section{Return On Asset (ROA)}

Menurut Firmansyah dan Nasrulloh (2016), terkait dengan kinerja, penilaian kinerja dari sudut finansial biasanya diukur dengan profitabilitas atau return on asset (ROA). ROA menunjukkan kemampuan perusahaan menghasilkan laba dari total aset yang dimilikinya. Jika ROA meningkat maka perusahaan dalam keadaan baik. Untuk mempertahankan kinerja keuangan tersebut, maka berbagai cara terbaik harus dilakukan manajemen perusahaan.
Selain itu, Siamat (2005) menuliskan bahwa rasio profitabilitas digunakan untuk mengukur efektifitas bank dalam memperoleh laba. Disamping dapat dijadikan sebagai ukuran kesehatan keuangan, rasio-rasio profitabilitas ini sangat penting untuk diamati mengingat keuntungan yang memadai diperlukan untuk mempertahankan arus sumbersumber modal. Oleh karena itu tingkat profitabilitas bank syariah yang tinggi akan memungkinkan bank untuk menyalurkan pembiayaan bagi hasil lebih besar kepada masyarakat.

Menurut Dendawijaya (2003) ROA merupakan rasio yang digunakan untuk mengukur kemampuan manajemen bank dalam memperoleh laba secara keseluruhan. Satu pendapat dengan Kuncoro (2002), Return on Asset (ROA) merupakan salah satu rasio profitabilitas, yang menunjukkan kemampuan manajemen bank dalam mengelola aktiva yang tersedia untuk mendapatkan net income.

Rumus untuk mengitung ROA adalah sebagai berikut :

$$
R O A=\frac{\text { Laba Sebelum Pajak }}{\text { Total Asset }} \times 100 \%
$$

Besarnya profitabilitas yang diterima oleh perbankan syariah, akan memberikan efek positif bagi kinerja keuangan. Selain itu meningkatkan 
kepercayaan bagi bank syariah dalam mengahadapi persaingan dengan lembaga keuanga lainnya.

\section{a. Financing to Deposti Ratio (FDR)}

Menurut Taswan (2006) LDR (Loan to Deposit Ratio) adalah perbandingan antara kredit yang diberikan dengan dana pihak ketiga (giro tabungan, deposito dan kewajiban jangka pendek lainnya). LDR (Loan to Deposit Ratio) dalam bank syariah disebut dengan Financing to Deposti Ratio (FDR).

Financing to Deposit Ratio (FDR) adalah perbandingan antara pembiayaan yang diberikan oleh bank dengan dana pihak ketiga yang berhasil dikerahkan oleh bank (Muhammad, 2005). Rasio FDR yang analog dengan Loan to Deposit Ratio (LDR) pada bank konvensional adalah rasio yang digunakan untuk mengukur seberapa jauh kemampuan bank dalam membayar kembali penarikan dana yang dilakukan deposan dengan mengandalkan pembiayaan yang diberikan sebagai sumber likuiditasnya (Dendawijaya, 2003).

Melihat definisi tentang FDR diatas, maka dapat diambil intisarinya bahwa, jika nilai FDR baik maka itu memberikan sebuah bukti bahwa kemampuan bank syariah memenuhi kewajibannya yaitu memenuhi kebutuhan dana yang akan ditarik oleh nasabah DPK yang sumbernya dari pengembalian pembiayaan yang telah diberikan. Itu artinya pembiayaan yang diberikan berada dalam posisi lancar, sehingga dengan demikian akan memberikan peningkatan terhadap profitabilitas.

Penelitian terdahulu tentang pengaruh FDR terhadap profitabilitas adalah Yunita (2014), Riyadi dan Waluyo (2014), Ali et al (2012) yang menyimpulkan bahwa FDR berpengaruh terhadap profitablitas (ROA). Ada juga hasil penelitian terdahulu yang memberikan kesimpulan bahwa FDR tidak berpengaruh terhadap ROA, seperti Suryani (2011).

Rumus untuk mengitung FDR adalah sebagai berikut :

$$
F D R=\frac{\text { jumlah pembiayaan yang disalurkan }}{\text { dana yang diterima bank }} \times 100 \%
$$

Berdasarkan kajian teori dan hasil penelitian sebelumnya, maka hipotesis yang diajukan adalah:

H1 : FDR Berpengaruh Positif terhadap Profitabilitas (ROA) Bank Syariah

\section{Dana Pihak Ketiga (DPK)}

Menurut Firmansyah dan Nasrulloh (2013), Bank adalah pelayanan masyarakat dan wadah perantara keuangan masyarakat. Karena itu bank harus selalu berada di tengah masyarakat agar arus uang dari masyarakat yang kelebihan dapat ditampung dan disalurkan pada 
Agus Ahmad N. : The Impact Of Micro Economics Factors on Financial Performance..

masyarakat yang kekurangan.

Kepercayaan masyarakat akan keberadaan bank dan keyakinan masyarakat bahwa bank akan menyelenggarakan sebaikbaiknya permasalahan keuangannya, merupakan suatu keadaan yang diharapkan oleh semua bank.

Dana pihak ketiga (DPK) merupakan dana yang bersumber dari masyarakat luas merupakan sumber penting untuk aktivitas operasional bank dan merupakan tolak ukur keberhasilan suatu bank apabila bank dapat menanggung biaya operasinya dari sumber dana ini (Kasmir, 2012).

Masih menurut Kasmir (2006), dana pihak ketiga adalah dana yang dihimpun oleh bank yang berasal dari masyarakat, yang terdiri dari simpanan giro, simpanan tabungan dan simpanan deposito.

Sumber dana ini merupakan sumber dana terpenting bagi kegiatan operasi suatu bank dan merupakan ukuran keberhasilan bank jika membiayai operasinya dari sumber dana ini. Pencairan dari sumber ini relatif paling mudah jika dibandingkan dengan sumber lainnya. Hal tersebut relevan dengan pendapat $\mathrm{M}$. Sinungan yang mengatakan bahwa (Sinungan, 2000):

"Dana-dana masyarakat yang disimpan dalam bank adalah merupakan sumber dana terbesar yang paling diandalkan bank dan terdiri dari tiga jenis, yaitu: giro (demand deposits), Deposito (Time Deposits), tabungan (Serving)".

Keberhasilan bank syariah dalam menghimpun dana pihak ketiga dari masyarakat, memberikan peluang besar bagi pihak bank syariah untuk memperoleh profit yang lebih besar dengan cara menyalurkannya dalam bentuk pembiayaan. Sumber modal bank syariah yang berasal dari DPK ini adala sumber modal yang paling murah jika dibandingkan dengan sumber-sumber modal yang lain, sehingga jika DPK yang berhasil dihimpun ini mampu disalurkan secara tepat dalam bentuk pembiayaan, maka akan meningkatkan profitabilitas bank syariah.

Rumus untuk menghitung DPK adalah sebagai berikut :

$$
D P K=\text { Giro }+ \text { Tabungan }+ \text { Deposito }
$$

Hasil penelitian tedahulu tentang pengaruh DPK terhadap ROA adalah Muliawati dan Khoirudin (2015), Muliawati Khoirudin (2015) yang memberikan kesimpulan bahwa DPK berpengaruh negative terhadap ROA. Berbeda dengan hasil penelitian Luciana (2011), menyatakan bahwa DPK tidak berpengaruh signifikan terhadap ROA.

Berdasarkan kajian teori dan hasil penelitian sebelumnya, maka hipotesis yang diajukan adalah: 
$\mathrm{H} 2$ : DPK Berpengaruh Positif terhadap Profitabilitas (ROA) Bank Syariah

\section{Pembiayaan}

Kegiatan menyalurkan pembiayaan adalah kesempatan emas yang dimiliki oleh bank syariah untuk mendapatkan profitabilitas. Bank syariah akan memperoleh keuntungan dalam bentuk bagi hasil atau margin. Jadi dengan semakin besarnya pembiayaan yang diberikan, maka akan memberikan harapan yang besar bagi bank syariah untuk meningkatkan kinerja keuangannya yaitu profitabilitas. Maka dari itu, pihak bank syariah harus pandai menjaga angka kemacetan, agar profitabilitas diperoleh dengan maksimal.

Terdapat penelitian terdahulu tentang pembiayaan, yaitu Inayatillah (2017), yang menyimpulkan bahwa pembiayaan jual beli berpengaruh terhadap profitabilitas sedangkan pembiayaan bagi hasil tidak berpengaruh. Oktriani (2012) Rahman \& Rochmanika (2012) yang memberikan kesimpulan bahwa pembiayaan memberikan pengaruh terhadap profitabilitas bank umum syariah. Pada penelitian ini, data pembiayaan yang dikaji adalah pembiayaan bagi hasil dan pembiayaan jual beli.

Rumus untuk mengitung DPK adalah sebagai berikut :
Pembiayaan = Ln_Pembiayaan Bagi Hasil + Ln_Pembiayaan Jual Beli

Berdasarkan kajian teori dan hasil penelitian sebelumnya, maka hipotesis yang diajukan adalah:

H3 : Pembiayaan Berpengaruh Positif terhadap Profitabilitas (ROA) Bank Syariah

\section{Non performing financing (NPF)}

Bank Syariah di dalam menjalankan kegiatan operasionalnya dihadapkan juga dengan berbagai resiko yang berkaitan dengan fungsinya sebagai perantara keuangan (intermediary), sehingga bank syariah sebagai suatu entitas bisnis juga mempunyai resiko atas kegiatan usahanya (Suhardjono, 2012).

Lukman Dendawijaya (2001) memberikan pengertian tentang Non Performing Financing (NPF) yaitu kredit yang kategori kolektibilitasnya masuk dalam kriteria kurang lancar, diragukan dan macet.

Non performing financing (NPF) adalah resiko yang melekat pada pembiayaan yang diberikan oleh bank syariah kepada nasabah, yaitu resiko gagal bayar atau ketidakmampuan nasabah untuk mengembalikan dana pembiayaan yang telah diterima baik pokok atau margin. Kondisi ini jelas akan menghambat tercapainya keuntungan yang sudah 
Agus Ahmad N. : The Impact Of Micro Economics Factors on Financial Performance..

diperhitungkan oleh pihak manajemen keuangan bank syariah.

Ditemukan penelitian terdahulu tentang pengaruh NPF terhadap ROA, seperti Muliawati dan Khoirudin (2015), Zulfiah dan Wibowo (2014) menyatakan bahwa NPF berpengaruh terhadap ROA. Akan tetapi berbeda dengan penelitian Wibowo dan Syaichu (2013), Riyadi dan Waluyo (2014), dan Ali et al. (2012), bahwa Non Performing Financing (NPF) menyatakan bahwa NPF tidak berpengaruh terhadap profitabilitas yaitu ROA

Rumus untuk mengitung NPF adalah sebagai berikut :

$$
\text { Rasio NPF }=\frac{\text { total NPF }}{\text { total pembiayaan }} \times 100 \%
$$

Berdasarkan kajian teori dan hasil penelitian sebelumnya, maka hipotesis yang diajukan adalah:

H4 : NPF Berpengaruh Negatif terhadap Profitabilitas (ROA) Bank Syariah

\section{B. Hasil Penelitian}

\section{Uji Asumsi Klasik}

\section{1) Uji Normalitas}

Uji normalitas bertujuan untuk menguji apakah dalam model regresi, variabel penganggu atau residual memiliki distribusi normal. Model regresi yang baik adalah memiliki distribusi data normal atau mendekati normal. Alat uji yang digunakan pada penelitian ini adalah uji statistik dengan Kolmogrov-Smirnov Z (ISample $K-S$ ). Dari tabel 2 diketahui bahwa besarnya nilai Asymp. sig (2-tiled) adalah 0,406 dan nilai tersebut lebih dari 0,05. Sehingga dapat disimpulkan bahwa data residual berdistribusi normal.

Tabel 2: Uji Normalitas

One-Sample Kolmogorov-Smirnov Test

\begin{tabular}{|ll|r|}
\hline & & Unstandardized Residual \\
\hline $\mathrm{N}$ & & 51 \\
Normal & Mean & .0000000 \\
Parameters & Std. & .88476480 \\
& Deviation & \\
Most Extreme & Absolute & .125 \\
Differences & Positive & .125 \\
& Negative & -.112 \\
Kolmogorov-Smirnov Z & .890 \\
Asymp. Sig. (2-tailed) & .406 \\
\hline a. Test distribution is Normal. \\
b. Calculated from data.
\end{tabular}

\section{2) Uji Non Multikolinieritas}

Uji non multikolinieritas bertujuan untuk menguji apakah dalam model regresi ditemukan adanya korelasi antar varibel independen. Model regresi yang baik adalah tidak terjadi korelasi yang tinggi diantara variabel independennya. Uji non multikoliniearitas dalam penelitian ini menggunakan nilai Tolerance dan Variance Inflation Factor (VIF).

Berdasarkan hasil perhitungan pada tabel 3 menunjukkan bahwa nilai VIF dari masing-masing variabel independen yaitu , FDR, DPK, NPF, dan Pembiayaan perbankan syariah di Indonesia berada di sekitar angka 1 (kurang dari angka 10), 
dan nilai tolerance (TOL) yang diperoleh menunjukkan nilai yang lebih besar dari 0,10. Dari hasil tersebut dapat diketahui bahwa dalam model regresi terbebas dari multikolinearitas antar variabel independen.

Tabel 3: Uji Multikolinieritas

\begin{tabular}{|c|c|c|c|}
\hline \multicolumn{4}{|c|}{ Coefficients $^{a}$} \\
\hline \multirow{2}{*}{\multicolumn{2}{|c|}{ Model }} & \multicolumn{2}{|c|}{ Collinearity Statistics } \\
\hline & & Tolerance & VIF \\
\hline \multirow[t]{5}{*}{1} & (Constant) & & \\
\hline & FDR & .504 & 1.986 \\
\hline & DPK & .108 & 9.259 \\
\hline & NPF & .813 & 1.231 \\
\hline & pembiayaan & .116 & 8.584 \\
\hline
\end{tabular}

a. Dependent Variable: ROA

\section{3) Uji Non Autokorelasi}

Uji non autokorelasi bertujuan untuk menguji apakah model regresi linier ada korelasi antara kesalahan pengganggu pada periode $t$ dengan kesalahan pengganggu pada periode $\mathrm{t}-1$ (sebelumnya). Dari hasil perhitungan pada tabel 4, Ternyata koefisien Durbin-Watson besarnya 1,908. Nilai tersebut berada di antara dU (1,7228) dan 4-dL(3,426). Daerah tersebut berada pada daerah tanpa kesimpulan, namun karena nilai DW mendekati angka 2 maka dapat disimpulkan bahwa dalam regresi antara variabel bebas terhadap variabel dependen tidak terjadi autokorelasi.

Nilai Durbin-Watson (DW) sebesar 1,908. Sedangkan berdasarkan tabel durbin
Watson (DW) dengan k=4 dan $\mathrm{n}=53$. Maka nilai $\mathrm{dL}=1,4000$ dan $\mathrm{dU}=1,7228$, maka 4-dU=2,2772 dan 4-dL=2,6000. Oleh karena itu nilai DW diantara nilai DU dan 4-DU maka dapat disimpulkan bahwa model persamaan regresi tersebut tidak mengandung masalah otokorelasi.

Tabel 4: Uji Non Autokorelasi

\begin{tabular}{|c|c|r|r|r|r|}
\hline & & $\mathrm{R}$ & Adjusted \\
Model & $\mathrm{R}$ & Square & R Square & $\begin{array}{c}\text { Std. Error of } \\
\text { the Estimate }\end{array}$ & $\begin{array}{l}\text { Durbin- } \\
\text { Watson }\end{array}$ \\
\hline 1 & $.913^{\mathrm{a}}$ & .833 & .819 & 1.38117 & 1.908 \\
\hline
\end{tabular}
a. Predictors: (Constant), pembiayaan, NPF, FDR, DPK
b. Dependent Variable: ROA

\section{4) Uji Heteroskedastisitas}

Gejala heteroskedastisitas ditunjukkan oleh koefisien regresi dari masing-masing variabel bebas terhadap nilai absolute residualnya. Jika nilai probabilitas lebih besar dari nilai alpha $(\operatorname{Sig}>\alpha)$, maka dapat dipastikan model tidak mengandung gejala. Berdasarkan nilai output pada tabel 5 di bawah, dapat diperoleh nilai signifikannya yaitu FDR 0,222, DPK 0,262, NPF 0,711 dan Pembiayaan 0,853. Nilai-nilai tersebut secara keseluruhan besarnya diatas nilai alpha yaitu 0,05. Sehingga dapat disimpulkan bahwa model regresi tersebut tidak mengandung gejala heteroskedastisitas. Artinya, jika nilai Sig $>$ alpha maka pada model tersebut tidak terjadi gejala heteroskedastisitas. 
Agus Ahmad N. : The Impact Of Micro Economics Factors on Financial Performance..

Tabel 5: Uji Heteroskedastisitas

Coefficients $^{\mathrm{a}}$

\begin{tabular}{|l|r|r|r|r|r|}
\hline \multirow{2}{*}{ Model } & \multicolumn{2}{|c|}{$\begin{array}{c}\text { Unstandardized } \\
\text { Coefficients }\end{array}$} & $\begin{array}{c}\text { Standardized } \\
\text { Coefficients }\end{array}$ & & \\
\cline { 2 - 4 } & \multicolumn{1}{c|}{$\mathrm{B}$} & Std. Error & \multicolumn{1}{|c|}{ Beta } & \multicolumn{1}{c|}{$\mathrm{t}$} & Sig. \\
\hline 1 (Constant) & 3.585 & 1.026 & & 3.495 & .001 \\
FDR & -.008 & .007 & -.234 & -1.237 & .222 \\
DPK & -.289 & .254 & -.464 & -1.134 & .262 \\
NPF & .011 & .029 & .056 & .373 & .711 \\
pembiayaan & .047 & .251 & .074 & .187 & .853 \\
\hline
\end{tabular}

a. Uji Hipotesis

Tabel 6 berikut adalah hasil pengujian SPSS ver. 16.0 regresi antara FDR, DPK, NPF dan Pembiayaan pada perbankan syariah di Indonesia tahun 2010-2015

Tabel 6: Model Summary Output SPSS Model Summary ${ }^{\mathrm{D}}$

\begin{tabular}{|l|c|r|r|r|}
\hline Model & $\mathrm{R}$ & $\mathrm{R}$ Square & $\begin{array}{c}\text { Adjusted R } \\
\text { Square }\end{array}$ & $\begin{array}{r}\text { Std. Error of } \\
\text { the Estimate }\end{array}$ \\
\hline 1 & $.913^{\mathrm{a}}$ & .833 & .819 & 1.38117 \\
\hline
\end{tabular}

a. Predictors: (Constant), pembiayaan, NPF, FDR, DPK

b. Dependent Variable: ROA

Nilai Adjust $R$ Square sebesar 0,833 yang artinya bahwa ROA dapat dijelaskan oleh keempat variabel independen yaitu FDR, DPK, NPF dan Pembiayaan sebesar $83,3 \%$ sedangkan sisanya sebesar $16,7 \%$ dijelaskan oleh faktor lain yang tidak diteliti.

\section{1) Uji Statistik F (F-test)}

Selanjutnya, berdasarkan uji statistik F pada Tabel 7, diketahui bahwa nilai $\mathrm{F}$ hitung sebesar 57,389 dengan nilai signifikansi sebesar $0,000 . \quad$ Nilai signifikansi tersebut kurang dari $\alpha(5 \%)$. Hal tersebut berarti model regresi dapat digunakan untuk memprediksi nilai ROA, atau secara simultan seluruh variable independen berpengaruh terhadap variable dependen.

Tabel 7: ANOVA Output SPSS

ANOVA $^{\text {b }}$

\begin{tabular}{|l|r|r|r|c|c|}
\hline \multicolumn{1}{|l|}{ Model } & $\begin{array}{r}\text { Sum of } \\
\text { Squares }\end{array}$ & Df & $\begin{array}{c}\text { Mean } \\
\text { Square }\end{array}$ & F & Sig. \\
\hline $1 \quad$ Regression & 437.908 & 4 & 109.477 & 57.389 & $.000^{\mathrm{a}}$ \\
Residual & 87.751 & 46 & 1.908 & & \\
\multicolumn{1}{|l|}{ Total } & 525.658 & 50 & & & \\
\hline
\end{tabular}

a. Predictors: (Constant), pembiayaan, NPF, FDR, DPK

b. Dependent Variable: ROA

\section{2) Uji Statistik t (t-test)}

Berdasarkan dari hasil pengujian statistik yang dilakukan sebagaimana yang tercantum pada tabel 8 , secara parsial hanya variable NPF yang berpengaruh terhadap ROA, sedangkan variable FDR, DPK dan Pembiayaan tidak memberikan pengaruh terhadap ROA.

Tabel 8: Coefficients Output Regression

Coefficients $^{\mathrm{a}}$

\begin{tabular}{|l|r|r|r|r|r|}
\hline & \multicolumn{2}{|c|}{$\begin{array}{c}\text { Unstandardized } \\
\text { Coefficients }\end{array}$} & $\begin{array}{c}\text { Standar } \\
\text { dized } \\
\text { Coefficie } \\
\text { nts }\end{array}$ & & \\
\cline { 2 - 4 } Model & \multicolumn{1}{c|}{$\mathrm{B}$} & Std. Error & \multicolumn{1}{c|}{ Beta } & \multicolumn{1}{c|}{$\mathrm{t}$} & Sig. \\
\hline 1 (Constant) & 3.368 & 1.536 & & 2.193 & .033 \\
FDR & .002 & .010 & .015 & .177 & .860 \\
DPK & -.445 & .381 & -.214 & -1.168 & .249 \\
NPF & -.624 & .044 & -.947 & - & .000 \\
pembiayaan & .358 & .376 & .168 & .951 & .347 \\
\hline
\end{tabular}

a. Dependent Variable: ROA

Berdasarkan tabel di atas maka dapat dibentuk suatu persamaan regresi yaitu sebagai berikut:

$$
\begin{aligned}
\mathrm{Y}= & 3,368+0,002 \mathrm{X}_{1 \mathrm{it}}-0,445_{2 \mathrm{it}}-0,624_{3 \mathrm{it}} \\
& +0,358_{4 \mathrm{it}}+\mathrm{e}
\end{aligned}
$$


Berikut ini dijelaskan hasil analisis uji hipotesis parsial (uji t) tentang variabel-variabel mikro yang mempengaruhi ROA perbankan syariah di Indonesia:

1. H1 : FDR berpengaruh positif terhadap ROA

Hipotesis pertama yang menyatakan bahwa FDR berpengaruh positif terhadap ROA hasilnya ditolak, karena nilai Sig. 0,860 > alpha 0,05.

Hasil penelitian ini sejalan dengan hasil penelitian sebelumnya yang dilakukan oleh Suryani (2011), menyatakan bahwa FDR tidak ada pengaruh terhadap profitabilitas yaitu ROA. Akan tetapi bertolak belakang dengan hasil penelitian sebelumnya yang dilakukan oleh Yunita (2014) Riyadi dan Waluyo (2014), Ali et al. (2012) yang menyatakan bahwa FDR berpengaruh terhadap profitabilitas (ROA).

FDR merupakan likuiditas, yaitu bagaimana bank syariah menampung dana sebanyak-banyaknya dari masyarakat kemudian menyalurkannya kembali dalam bentuk pembiayaan, dimana ketika bank syariah menyalurkan dana tersebut kepada masyarakat, maka FDR nya akan menjadi kecil. Kondisi yang baik itu adalah dana berhasil dihimpun dalam bentuk DPK lebih banyak dari apa yang disalurkan, sehingga FDR nya besar. Akan tetapi berbeda kondisinya jika setiap uang yang tersimpan pada DPK dan disalurkan lagi kepada nasabah, yang jadi dibicarakan adalah hanya seberapa besar bank syariah menyalurkan saja, bukan seberapa besar laba yang diperoleh, karena bisa jadi dana yang disalurkan kepada nasabah itu jumlahnya banyak, akan tetapi belum tentu mendatangkan keuntungan, seperti dengan akad mudharabah dan musyarakah, dimana nasabah penerima dana memungkinkan tidak memperoleh keuntungan dari dana pinjaman tersebut, sehingga dampak terhadap ROA nya tidak ada.

2. H2 : DPK berpengaruh positif terhadap ROA

Hipotesis kedua yang menyatakan bahwa DPK berpengaruh positif terhadap ROA hasilnya juga ditolak, karena nilai sig. 0,249 > alpha 0,05. Hasil penelitian ini sama dengan penelitian sebelumnya yaitu Luciana (2011) menyatakan bahwa DPK tidak berpengaruh terhadap ROA, tapi yang menjadi pembedanya adalah tidak berpengaruhnya itu secara signifikan terhadap ROA, sedangkan pada penelitian ini DKP tidak berpengaruh dan tidak signifikan terhadap ROA.

Selain ada yang sama dengan penelitian terdahulu, hasil penelitian ini pun ada yang berbeda dengan penelitian sebelumnya, seperti Muliawati dan 
Agus Ahmad N. : The Impact Of Micro Economics Factors on Financial Performance..

Khoirudin (2015), yang memberikan kesimpulan bahwa variabel DPK berpengaruh negative terhadap ROA.

DPK artinya dana yang ditampung dari masyarakat dalam bentuk deposito, giro dan tabungan. Jika DPK ini tidak disalurkan kepada masyarakat dalam bentuk pembiayaan, otomatis tidak akan berpengaruh terhadap ROA. Jadi DPK itu berbicara tentang bagaimana uang yang dihasilkan atau berhasil dihimpun dari masyarakat disalurkan kembali kepada produk-produk yang sesuai dan yang diharapkan memperoleh keuntungan. Kesimpulannya, jika DPK tinggi tapi tidak disalurkan kepada nasabah dalam bentuk pembiayaan, maka tidak akan menjadi keuntungan. Begitupun sama, jika DPK tinggi kemudian disalurkan kepada nasabah dan tidak tepat sasaran dalam menyalurkannya maka tidak akan menjadi keuntungan seperti FDR. Intinya, besarnya DPK belum tentu berpengaruh terhadap profitabilitas (ROA), kalau manajemen bank syariah tidak baik dalam mengelola keuangan.

3. H3 : Pembiayaan berpengaruh positif terhadap ROA

Hipotesis ketiga yang menyatakan bahwa pembiayaan berpengaruh positif terhadap ROA hasilnya adalah ditolak. Nilai sig yang diperoleh 0,347> alpha 0,05 .
Hasil penelitian ini sejalan dengan penelitian sebelumnya yaitu Inayatillah (2017), bahwa pembiayaan bagi hasil tidak berpengaruh terhadap ROA, sedangkan pembiayaan jual beli berpengaruh terhadap ROA. Pada penelitian ini tidak berpengaruhnya adalah kedua jenis pembiayaan, yaitu bagi hasil dan jual beli. Bertolak belakang dengan penelitian Oktriani (2012), Rahman \& Rochmanika, yang memberikan kesimpulan bahwa pembiayaan berpengaruh terhadap ROA.

Pembiayaan belum tentu berpengaruh terhadap ROA kalau manajemen tidak menyalurkannya dengan baik dan benar. Jika bank syariah tidak memiliki manajemen pembiayaan dan keuangan yang baik, maka bisa jadi pembiayaan itu tidak berpengaruh terhadap profitabilitas. Mungkin periode pada penelitian ini, bank syariah yang menjadi sampel itu memiliki kondisi dimana pembiayaan itu tidak pasa disalurkan kepada nasabah, atau bisa juga karena banyaknya nasabah yang gagal dalam usahanya karena faktor makro ekonomi, seperti kebijakan fiskal atau kebijakan moneter.

FDR, DPK dan Pembiayaan merupakan rasio keuangan yang saling berhubungan yaitu antara peyaluran dana dengan penerimaan dana, sehingga 
menurut peneliti, hasil temuan dalam penelitian ini dikatakan wajar ketiga variabel tersebut tidak memberikan pengaruh terhadap profitabilitas (ROA).

4. H4 : NPF berpengaruh negative terhadap ROA

Hipotesis keempat yang menyatakan bahwa NPF berpengaruh negative signifikan hasilnya diterima, dibuktikan dengan nilai sig. $0,000<$ alpha 0,05 . Artinya jika nilai NPF turun, maka akan mengakibatkan meningkatnya profitabilitas (ROA), atau sebaliknya jika NPF naik maka akan menyebabkan menurunnya profitabilitas (ROA).

Hasil penelitian ini senada dengan penelitian lain yang telah dilakukan oleh Muliawati dan Khoirudin (2015), Zulfiah dan Wibowo (2014) yang memberikan kesimpulan bahwa NPF berpengaruh positif signifikan terhadap ROA. Akan tetapi berbeda dengan penelitian Wibowo dan Syaichu (2013), Riyadi dan Waluyo (2014), dan Ali et al. (2012), bahwa Non Performing Financing (NPF) menyatakan bahwa NPF tidak berpengaruh terhadap profitabilitas yaitu ROA.

NPF merupakan rasio tingkat kemacetan dari pembiayaan yang disalurkan. Besar kecilnya NPF tergantung pada kemampuan manajemen pembiayaan bank syariah dalam memantau/mengawasi atau bahkan menangani pembiayaan yang telah disalurkan agar tidak mengalami kemacetan, yang dapat menyebabkan tidak mampunya nasabah dalam mendapatkan keuntungan atau bahkan mengembalikan dana yang telah diterima dari bank syariah.

Maka berdasarkan hasil penelitian ini, NPF memberikan pengaruh negative dan signifikan, itu artinya jika nilai NPF mengalami kenaikan maka dampakya akan mengakibatkan profitabilitas (ROA) yang diterima oleh bank syariah akan kecil. Sebaliknya jika nilai NPF bank syariah kecil atau mengalami penurunan, maka akan mengakibatkan profitabilitas (ROA) yang diterima akan mengalami peningkatan.

\section{SIMPULAN}

Berdasarkan hasil uji analisis data, pengujian hipotesis dan pembahasan yang telah diuraikan, dan pembahasan, maka dapat diambil kesimpulan bahwa pengaruh faktor-faktor variabel mikro terhadap profitabilitas (ROA) perbankan syariah di Indonesia adalah sebagai berikut:

1. FDR tidak berpengaruh terhadap ROA Kondisi ini mungkin disebabkan oleh jumlah pembiayaan yang diberikan yang sumbernya dari DPK memang besar, akan tetapi tidak mendatangkan keuntungan karena kualitas portofolio nasabah yang tidak baik dan mengakibatkan likuiditas 
Agus Ahmad N. : The Impact Of Micro Economics Factors on Financial Performance..

terganggu, sehingga tidak berpengaruh terhadap profitabilitas.

2. DPK tidak berpengaruh terhadap ROA

Besarnya DPK yang berhasil dihimpun belum tentu memberikan keuntungan, apabila DPK tersebut tidak disalurkan secara maksimal atau salah sasaran dalam bentuk pembiayaan.

3. Pembiayaan tidak berpengaruh terhadap ROA

Tidak berpengaruhnya pembiayaan terhadap ROA mungkin disebabkan oleh manajemen dan analisa pembiayaan yang tidak baik, sehingga mengakibatkan tidak lancarnya penerimaan bank dalam bentuk margin atau bagi hasil dari nasabah pembiayaan tersebut.

4. NPF berpengaruh negative terhadap ROA

Kemampuan perbankan syariah dalam mengatasi dan mengantisipasi pembiayaan bermasalah, mengakibatkan lancarnya pengembalian pembiayaan dari nasabah, sehingga apabila NPF nya berhasil dikelola maka akan mempengaruhi profitabilitas bank syariah. Artinya, jika nilai NPF naik maka akan menurunkan profitabilitas, dan jika NPF turun maka akan meningkatkan profitabilitas.

\section{DAFTAR PUSTAKA}

Dendawijaya, Lukman. (2003). Manajemen Perbankan, Edisi kedua. Jakarta: Ghalia Indonesia.

Dendawijaya, Lukman. (2001). Manajemen Perkreditan. Jakarta:Ghalia Indonesia

Firmansyah, Irman dan Nasrulloh, Agus Ahmad. (2015). Mengapa Efisiensi Tidak Meningkatkan Kinerja Bank Syariah?. Makalah pada Call for Paper Forum Riset Ekonomi dan Keuangan Syariah (FREKS) IV. Universitas Brawijaya, Malang

Firmansyah, Irman. (2017), Comparison Analysis Of Influence Of Current Ratio On Financial Performance. Jurnal Akuntansi, Vol 12, 2, Juli Desember 2017

Firmansyah, Irman dan Nasrulloh, Agus Ahmad. (2013). Analisis Pembiayaan Bagi Hasil Pada Bank Umum Syariah di Indonesia. Jurnal Ekonomi dan Bisnis Islam, Vol. III No. 1. Pusat Studi dan Bisnis Islam. Fakultas Ekonomi dan Bisnis. Universitas Padjadjaran

Firmansyah, Irman dan Nasrulloh, Agus Ahmad. (2016). Analisis Stabilitas Efisiensi dan Kinerja Asuransi Syariah dalam Menunjang Pertumbuhan IKNB Syariah. Makalah pada Call for Paper Forum Riset Ekonomi dan Keuangan Syariah (FREKS) XIV. IAIN Imam Bonjol Padang.

Ghozali, Imam. (2009). Aplikasi Analisis Multivariate dengan Program SPSS. Semarang: Badan Penerbit Universitas Diponegoro

Inayatillah, Yulia . (2017). Pengaruh Pembiayaan Bagi Hasil, Jual Beli, Fdr, Npf Terhadap Profitabilitas 
Bank Syariah. Jurnal Ilmu dan Riset Akuntansi, Volume 6, Nomor 12, Desember 2017, Sekolah Tinggi Ilmu Ekonomi Indonesia (STIESIA), Surabaya

Kasmir. (2012). Bank \& Lembaga Keuangan Lainnya. Jakarta: PT. Raja Grafindo Persada.

Kasmir. (2006). Manajemen Perbankan. Jakarta: RajaGrafindo Persada

Kuncoro, Mudrajad dan Suhardjono. (2002). Manajemen Perbankan Teori dan Aplikasi. Yogyakarta: Penerbit BPFE.

Luciana, T. (2013). Pengaruh Risiko Pembiayaan, Kecukupan Modal dan Dana Pihak Ketiga terhadap Profitabilitas pada Bank Umum Syariah di Indonesia. Skripsi. Semarang: Jurusan Akuntansi Fakultas Ekonomi Universitas Jember.

Muhammad. (2005). Manajemen Dana Bank Syariah. Ekonisia: Yogyakarta.

Muhammad. (2002). "Manajemen Bank Syariah". Edisi revisi. Yogyakarta.: UPP AMP YKPN

Muliawati, Sri dan Khoirudin, Moh. (2015). Faktor-faktor penentu profitabilitas bank syariah di Indonesia. Manajemen Analysis Journal 4. Universitas Negeri Semarang.

Oktriani, Y. (2012). Pengaruh Pembiayaan Musyarakah, Mudharabah dan Murabahah Terhadap Profitabilitas, E-journal Accounting, 1(1).

Rahman, A.,F., \& Rochmanika, R. (2012). Pengaruh Pembiayaan Jual Beli, Pembiayaan Bagi Hasil, dan Rasio
Non Performing Financing Terhadap Profitabilitas Bank Umum Syariah Di Indonesia. Iqtishoduna, 8(1).

Riyadi, S \& Yulianto, A. (2014). Pengaruh Pembiayaan bagi Hasil, Pembiayaan Jual Beli, Financing to Deposit Ratio (FDR) dan Non Performing Financing (NPF) terhadap Profitabilitas Bank Umum Syariah di Indonesia. Accounting Analysis Journal. 3 (4). Jurusan Akuntansi. Fakultas Ekonomi, Universitas Negeri Semarang, Indonesia

Sabir, M., Ali, M \& Habbe, A. H. (2012). Pengaruh Rasio Kesehatan terhadap Kinerja Keuangan Bank Umum Syariah dan Bank Konvensional di Indonesia. Jurnal Analisis. 1 (1): 7986.

Siamat, Dahlan. (2005). Manajemen Lembaga Keuangan, Edisi Keempat, Badan Penerbit Fakultas Ekonomi Universitas Indonesia. Jakarta

Sinungan, Muchdarsyah. (2000). Manajemen Dana Bank. Jakarta: Bumi Aksara

Suhardjono. (2003). Manajemen Perkreditan. Jakarta: UPPAMPYKPN

Suryani. (2011). Analisis Pengaruh Financing to Deposit Ratio (FDR) terhadap Profitabilitas Perbankan Syariah di Indonesia. Jurnal Walisongo. 19 (1).

Taswan. (2006). Manajemen Perbankan Konsep Teknik \& Aplikasi. Yogyakarta: UPP STIM YKPN Yogyakarta.

Yunita, Rima. (2014). Faktor-Faktor Yang Mempengaruhi Tingkat Profitabilitas Perbankan Syariah Di Indonesia (Studi Kasus pada Bank Umum 
Agus Ahmad N. : The Impact Of Micro Economics Factors on Financial Performance..

Syariah di Indonesia Tahun 2009 2012). Jurnal Akuntansi Indonesia. Vol. 3 No. 2 Juli 2014. Hal. 143 160

Zulfiah, F \& Wibowo, J. S. (2014). Pengaruh Inflasi, BI Rate, Capital Adequancy Ratio (CAR), Non Performing Financing (NPF), Biaya Operasional dan Pendapatan Operasional (BOPO) terhadap Profitabilitas Bank Umum Syariah Periode 2008-2012. Jurnal Ilmu Manajemen 
Amwaluna: Jurnal Ekonomi dan Keuangan Syariah, Vol 2 No. 2 Juli 2018, Hal 205-221 